\title{
Federal government financing of grassroots decay in Nigeria: the case of Edo state
}

\author{
Sylvanus I. Ebohon' \\ Department of Political Science and Public Administration, University of Benin, Nigeria \\ siebohon@yahoo.com
}

\begin{abstract}
In this research article, an attempt is made to locate the failure of local government councils to construct rural development poles in the context of patrimonial redistributive politics that greeted the emergence of the Nigerian petrostate. The failure of the third tier to transit into a local pole of development, controverts the assumed linkage between grassroots development and creation of more local government councils. Empirical evidence from Edo state has demonstrated 'reverse resource flow' in favour of urban and semi-urban locales. In this process, enhanced revenue flow through federal statutory allocation is 'reverse transfer' to the centres through the mechanisms of urban extractive ratio. The de-poling so engendered creates more decay than existed pre-fragmentation. By the character logic and organization of these new local governments (political post); they mediate the crisis of rural-urban exploitation and rural-locale depoling, in a self-reproduction project typical of patron-client politics. In this context, it is assumed that phenomenal growth in statutory and allied revenues accruing to rural locales has not produced the desired development, but undesired decay.
\end{abstract}

Key Words: Nigeria - Federal financing, Edo State, public administration, political science, Nigeria, University of Benin

\section{Introduction}

The centrality and attraction of the locale; the community, the village, the ethnic and sub-ethnic units in the construction of the colonial state apparatus was celebrated with the adoption of the dual mandate: (a) non-interference with native institutions and culture; (b) the preparation of the colonial peoples for self-rule. This was a response for the challenge of constructing a multi-centric national state that could accommodate divergence and stimulate a development profile driven by local peculiarities and challenges. This context and thrust were re-enacted in the post-colonial society at the Cambridge Conference on Local Government in Africa (196I)

' $\ldots$ it was observed that most African countries are heterogeneous and thereby contained within them potentially disruptive minorities which if not handled with care will constitute a threat to national unity. Consequently, this threat to national unity can be greatly reduced or entirely removed by the institution of Local Government ...

It was assumed that when Local Government are properly organized, they can serve as the best vehicles for taking into account, the interest of minorities and bringing them into a general or broader framework of national unity (quoted in Aghayere, 1995:275).

Cast in this mood, the Nigerian state, colonial and post-colonial, imbibed one fundamental conception of local government as the building block of national unity and development. It is in this context that the notion of grassroots development strategy is situated. This conception of development from below is organized around the institution of the government (Aghayere 1995, Ademolekun 1983, Oduola 1981). Three objectives of the Nigerian local government are (a) Participation (b) Resource mobilization, and (c) Provision of essential services. It is in line with government's firm persuasion in the centrality of local government that a third tier status was granted to the local government level as in Brazil (Erero 1998). Certain checks and balances which do not allow the state to exercise absolute control over the local government council in its operation as a third tier government include its guaranteed existence as in Section 7 of the 1999 constitution; financial allocation from the federation account; and the involvement of the local government council in economic planning of the state government (Imhanlihimi and Ikeanyibe 2009:77).

There are various phases of the local government system in Nigeria. These are (I) the colonial phase, (2) the local government reforms of the 1950s, (3) the military coup of $199 \mathrm{I}$ and the 1976 local government reforms. With the antilocal authority system mobilization against the colonial state by Chief Obafemi Awolowo in the West and Dr. Zik in the East, a reform process that created a three tier local government system via: (a) county or division (b) district and (c) local council was institutionalized in 1950. During the post-coup and post-war years, this new structure was differently understood and applied by the military governors either as "Native Authority, local government authority" development

I. Sylvanus Ebohon, PhD (Manchester), is a senior ecturer in the Department of Political Science and Public Administration at the University of Benin, Nigeria 
area”, development administration, etc. in various states without the needed uniformity. The confusion triggered the need for unification of the Nigerian local government system which was implemented by the Murtala Muhammed Administration in 1976. With the 1976 reform, the country adopted a single-tier system of local government which must be operationalised all over the federation. The focus of this reform was uniformity of:

(a) The functions of the local government;

(b) The structure of local government;

(c) The financial resources of local government;

(d) The place of traditional rulers in local government;

(e) The relationship with the state government; and

(f) Law enforcement.

This uniformity was further promoted by the Civil service reform of I 988 which enabled Babangida to radically transform and professionalise the service and the local government system.

In doing this, the presidential system which had been applied at the federal and state levels was introduced at the local level for clearer separation of power and checks and balances at grassroots. In this system, the chairman is not a member of the council but the executive head, with the entire L.G.A as his constituency. In the same vein, the executive supervisor without legislative responsibility was now introduced at the grassroot as it applied at the state and federal levels. With these reforms, the Nigerian local government system has come a long way. Issues that are now emerging are (I) how has the spate of reform patronage translated into grass roots governance as an arena of development process. What does the reform mean for the government at the state and federal levels in terms of grassroots instrumentality of governance and development? What has happened to grassroots resource Profile in the context of institutional leverage? Can the grassroots drive rural development? In addressing these issues, the paper is discussed in five sections. Section one address introductory and background issues while rural resource retention capacity as our framework of analysis is articulated in section II. Section III presents the resource profile of Edo state local government councils while section IV presents resource utilization as development cost. The theme, Edo drama of development is articulated in the concluding section.

\section{The framework: local resource retention capacity.}

The primary goal of creating a third tier is to switch development backward through the construction of new local poles of development. The mission is propelled by the need to de-concentrate development resources around the center and around the urban locales with a view to arresting the rising trend of rural-urban disarticulation and incoherence, characteristic of the Nigerian Spatial development profile. This traditional character has been marked by reverse resource transmission, rural resource depletion, rising rural poverty, rural infrastructural under development, urban over population, urban unemployment, rising urban social segmentation, and the attendant social maladjustment manifested in increased crime wave, declining moral value and social decay.

The creation of new local government is not necessarily synonymous with the creation of new resource domain or new poles of development in culturally multi-centric society, based on diverse and competing centers of external loyalty. The capacity to retain local resources or local surplus value depends on local availability of critical infrastructure. The creation of local resource domain depends on the local government's capacity to locally retain surplus value. The evolution of a local development pole within the LGA is dependent on the LGAs local resource retention capacity. In the absence of a local development pole, reverse resource transfer to alternative centers of development outside the local government take root. In the process, the L.G.A suffers from the crisis of runaway development. Local resource retention capacity therefore is the measure of the absorptive capacity of the L.G.A. to locally retain the values appropriated by the newly created L.G.A. Such appropriated values find their way back to their origins; state or federal in the context of low local absorptive capacity. Enhanced local absorptive capacity is therefore a necessary condition for the evolution of local poles of development. Figure I below captures the possible relationship between rural (LGA) local development poles and urban (external) competing development pole. 
$\begin{array}{lll}\text { LRRC }^{1} & \text { LRRC LRRC }\end{array}$

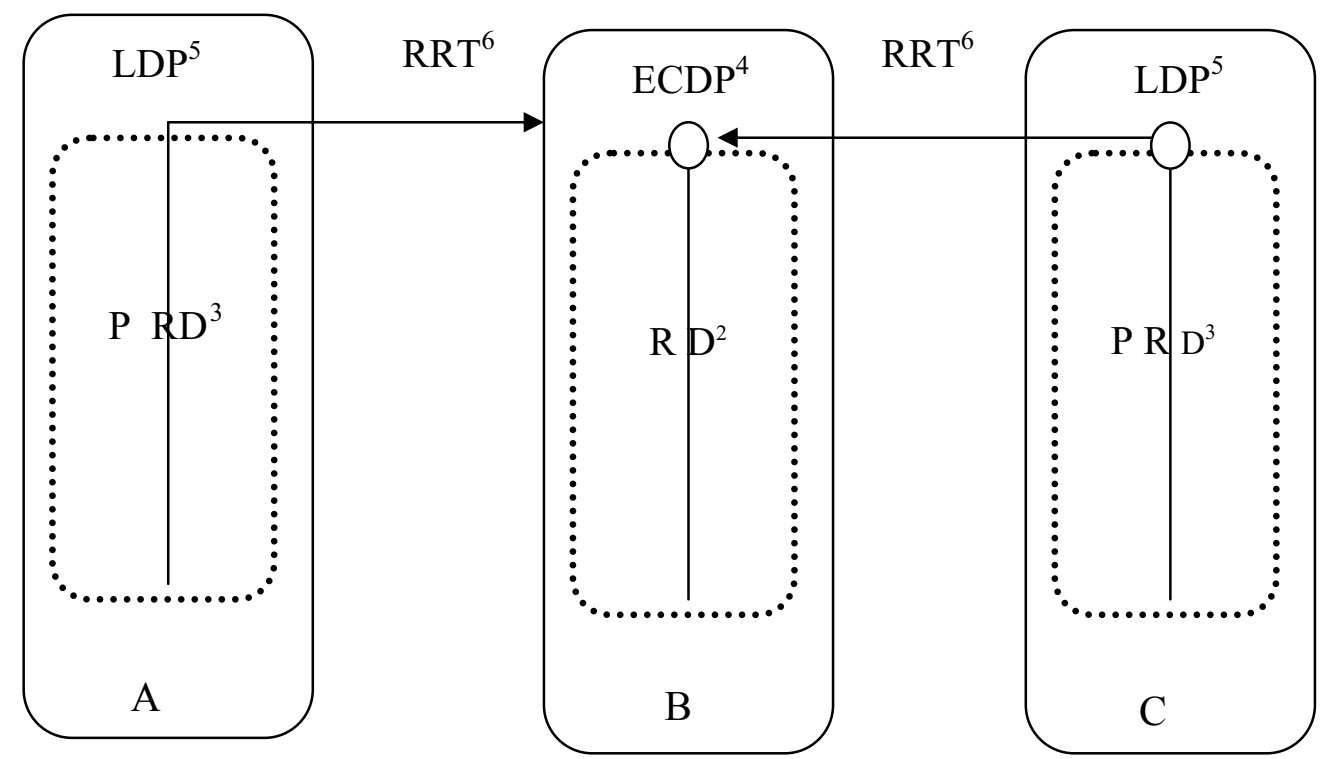

Figure1 Outcome possibilities of differential LRRC for Local Government Councils in Edo State Source: Ebohon (2008)

Key:

LRRC:

Local Resource Retention capacity

$-1$

RD:

Resource Domain

PRD:

Partial Resource Domain

ECDP:

External competing Dev. Pole

L.D.P:

Local Dev. Pole

$-5$

R.R.T:

Reverse Resource Transfer

As presented in Figure I, LRRC captures the capacity of a local government to retain resources locally (i.e. within) the local government, around development poles A, B, C, LPD as in A \& C are local poles of development while ECDP is an external competing development pole, attracting resources from LDP in a relationship of urban extractive ratio that exploits the rural LGAs through resource centralization around urban development pole. RRT is the process of rural resource transfer from underdeveloped rural enclave to a developed urban enclave, i.e. ECDP, while the three poles are development poles drawing resources from the centre. A \& $C$ transfer their weak resources to $B$. In this process, B strengthens as a resource domain while $A \& C$ degenerates into a partial resource domain. The concepts of vertical departmentalism, resource domain, rural retention capacity and reverse resource transfer have been articulated in Ebohon (1995:320-322)

Situation analysis:

The human and financial resources available to councils have been in steady increase since 1999. This trend has not been felt in terms of the development dreams that informed the demands for the creation of local government councils. The failure of councils to play such developmental role is informed by their inability to retain resources locally for development. Some observations will suffice in this respect.

(a) while average monthly statutory allocation for each council in Edo state has risen from NIOm in 1999 to about N50m by 2008, the development index has suggested decay or at best stagnation;

(b) The earnings of 75-85 percent of senior staff which account for more than 80 percent of wage bill is not utilized or invested in the local economy; it is rather transferred to the metropolitan Benin-City economy where they live with their children; 
(c) This figure is as high as 10 percent from the south senatorial district who worked in Benin, where all staff of the rural local government-Uhunmwode, Orhionmwon, Ovia south west and Ovia North east domicile in Benin City, with their families.

(d) The trends towards increased appropriation for recurrent and overhead expenditure, which averages 60 percent-70 percent of council's budget and which is controlled by the same cadre, further escalates the rising incidence of urban extractive ratio and reverse resource flow.

(e) The fact that 100 percent of the major contractors handling capital projects are domiciled in Benin City, even when they are indigenes of the local government area, further questions the structure of opportunity utilization and the urban extractive ratio;

$(f)$ The movement of the young youths and successful rural dwellers to Benin City, who accumulate through the councils, for building of modern urban structure as a first home concept, and functional rural structure as a second home concept to the neglect of their ancestral homes and shrines, clearly mark the failure of rural LGAs as development poles;

(g) The high incidence of reverse resource flow, so engendered has spelt runaway development and runaway opportunities in the context of rural LGAs. This crisis must be situated in the context of low resource retention capacity, and the absence of a local development pole within the rural local government areas;

(h) The incidence of runaway opportunities and runaway development does not only strengthen the urban development pole, it also depoles the rural enclave.

\section{The functions of local government councils:}

The 1976 local government reforms which created unified local government councils for the first time in the history of Nigerian grassroot government also identified and classified local government functions into three categories. This is in line with its new scope and responsibilities. These functions were later recaptured under schedule four of the 1979 constitution and schedule four of the 1989 constitution which was actually never operational. The 1999 constitution also outlined similar functions for the third tier under the fourth schedule (1999:LLI96-097) section 7. These functions are often locally and environmentally circumscribed. They include:

(a) Those functions which require detailed local knowledge for efficient performance.

(b) Functions in which success depends on community's responsiveness and participation.

(c) Functions which are of personal nature, requiring close to where the individual's affected live; and

(d) Functions in which significant use of discretion or understanding of individuals is needed (Local Government

Gazette 1980; Agahyere 1995:295).

I. The main functions of a local government council are as follows:

(a) The consideration and making of recommendation to a state commission on economic planning or any similar body on,

I The economic development of a state particularly in so far as the areas of authority of the council and of the state are effected and.

II Proposal made by the said commission or body:

(b) Collection of rates, radio and television license;

(c) Establishment and maintenance of cemeteries, burial ground and home of the destitute or infirm;

(d) Licensing of bicycles, trucks (other than mechanically propelled trucks).canoes, wheelbarrow and carts;

(e) Establishment, maintenance and regulation of slaughter houses, slaughter slabs, markets, motor parks and public conveniences;

(f) Construction and maintenance of roads, streets, street lightings, drains and other public highways, parks, gardens, open space, or such public facilities as may be prescribed from time to time by the house of assembly of a state;

(g) Naming of roads and streets and numbering of houses:

(h) Provision and maintenance of public convenience, sewage and refuge disposal;

(i) Registration of all births, deaths and marriages;

(j) Assignment of privately owned houses or tournaments for the purpose of playing such games as may be prescribed by the house of assembly of a state; and

(k) Control and regulation of:

I outdoor advertising and hoarding;

II movement and keeping of pets of all descriptions;

III Shops and kiosks;

Inkanyiso, Jnl Hum \& Soc Sci 20I I, 3(I) 
IV Restaurants, bakeries and other places for sale of food to the public;

$\checkmark$ Laundries; and

VI Licensing, regulation and control of the sale of liquor.

2. The function of a local government council shall include participation of such council in the government of a state as respect the following matters.

(a) The provision and maintenance of primary, adults and vocational education;

(b) The development of agriculture and natural resources, other than the exploration of minerals;

(c) The provision and maintenance of health service; and

(d) Such other functions as may be conferred on a local government council by the house of assembly of the state.

\section{Grassroots resource profile}

Grassroot resource profile in Nigeria has been undermined by the unstreamlined and uncoordinated history and structure of the Nigerian local government from the early days of the local authority to 198I. In effect, even in the face of the great reform of 1976, financial arrangement for the third tier remained either a pittance or a token or an unstable gesture from the central government. This development undermined the claim and pretensions of creating an autonomous local tier. The situation was not helped by the paucity of independent revenue available to the local council (Ebohon 1995:308) As Wraith (1972:1 19-120) observed: 'In many other countries, among them Canada and the United States, New Zealand, Sweden, West Germany and Switzerland, the average amount raised locally is about 70 percent and local government is proportionately more independent' (Also quoted in Imam, 1990).

Two observations informed by empirical evidence are germane on the issue of grassroots financing by the center. The first is that the early history of local financing has been characterized by epileptic disbursement not based on a regular sharing formula. When the third tier gained recognition through the reform of 1976, allocation was an ordinary token, not matched by policy proclamation and the dream of local transformation (see table I).

Table I Statutory allocation from the federal government to local government 1976/77-86

\begin{tabular}{llll}
\hline YEAR & TOTAL FEDERAL GOVT. REVENUE (N MILLION) & AMOUNT ALLOCATED TO LOCAL GOVT. (N MILLION) & \% \\
\hline $1976 / 77$ & $6,765,9$ & 100.00 & 1.48 \\
\hline $1977 / 78$ & $8,042.4$ & 250.00 & 3.11 \\
\hline $1978 / 79$ & $7,469.3$ & 150.0 & 2.01 \\
\hline $1979 / 80$ & $11,809.1$ & 344.3 & 2.92 \\
\hline 1980 & $11,859.8$ & 278.0 & 2.34 \\
\hline 1981 & $14,757.7$ & $1,085.0$ & 7.36 \\
\hline 1982 & $10,617.7$ & $1,018.7$ & 9.59 \\
\hline 1983 & $10,947.4$ & 996.8 & 9.10 \\
\hline 1984 & $11,738.5$ & $1,061.5$ & 9.04 \\
\hline 1985 & 15.041 .8 & $1,327.5$ & 8.82 \\
\hline 1986 & $14,189.9$ & $1,166.9$ & 8.22 \\
\hline
\end{tabular}

Source: Central Bank of Nigeria, Annual Report and Statement of Accounts for the various years listed. Also see Ebohon (1995).

Thus, the structure took the profile of window dressing constructed to legitimise authoritarianism at the grassroots. However, rising from a poor level of $1.48 \%$ of federation account allocation of 1976/77 to the current level of $20 \%$ implies a remarkable improvement, although capacity for rural transformation is still being tested. See Table 2 below for federal account structure $I^{\text {st }}$ half $200 I$ to $I^{\text {st }}$ half 2005 , for Edo state.

Table 2 Allocation to Edo state local government \& VAT pool account. N.M. Ist half 200 I - Ist half 2005

\begin{tabular}{llllll}
\hline & IST HALF & IST HALF & IST HALF & IST HALF & IST HALF \\
& $\mathbf{2 0 0}$ I & $\mathbf{2 0 0 2}$ & $\mathbf{2 0 0 3}$ & $\mathbf{2 0 0 4}$ & $\mathbf{2 0 0 5}$ \\
\hline State & $4,202.3$ & 4966.8 & $6,967.4$ & $9,381.1$ & $10,864.2$ \\
\hline I8 L.G.A & $3,002.6$ & $3,287.0$ & $4,541.8$ & $5,644.8$ & $6,136.4$ \\
\hline
\end{tabular}

Source: Adapted from CBN Economic report for first half of 2005. 
Table 2 above suggests a speedy increase in local government revenue profile since $200 \mathrm{I}$. However, it tells nothing about state statutory revenue contributions that accrue to the L.G.A from the state internally generated revenue. This revenue source has ceased to be a feature of the external revenue profile of Bendel State and later Edo state since I99I. Throughout the first 10 years of the $4^{\text {th }}$ republic, the 10 percent was never disbursed to local government councils in Edo state. Since the present Edo state administration, this negative profile has risen to 20 percent in the light of the monthly deduction of 10 percent by the state government from the federal allocation due to the LGA. In effect a council losses 20 percent of its statutory revenue on a monthly basis to the state government.

Closely related to the federal and state allocations is the issue of internal revenue generation and performance by the Local Government Council. Internal Revenue performance is generally poor and of course on a steady decline due to rising reliance on federal allocation by local government councils.

The internal revenue performance of the 18 local government councils in Edo state since 1999 is captured in table 3 below. This table must be viewed as couplet with table 4 which captures the national profile. The general downward trend suggest a demobilization and under employment of local resources, extraversion of local accumulation logic and the political and economic de-empowerment of the local people. Although table 3 shows some unstable pockets of performance, the general picture is gloomy threat of decay.

Table 3 Internal revenue contribution as percentage of total revenue

\begin{tabular}{lllllll}
\hline $\mathbf{s} / \mathbf{n}$ & Local govt. Council & $\mathbf{1 9 9 9}$ & $\mathbf{2 0 0 0}$ & $\mathbf{2 0 0 I}$ & $\mathbf{2 0 0 6}$ & \% Difference 1999-2006 \\
\hline $\mathrm{I}$ & Akoko-Edo & 2.72 & 1.78 & 1.13 & 1.2 & -126.7 \\
\hline 2 & Egor & 6.3 & 2.79 & 2.92 & 2.4 & -162.5 \\
\hline 4 & Esan Central & 0.001 & 1.25 & 1.82 & 1.2 & 99.9 \\
\hline 5 & Esan North East & 3.46 & 2.44 & 2.16 & 4 & 13.5 \\
\hline 6 & Esan South East & 1.6 & 1.1 & 0.8 & 0.6 & -166.7 \\
\hline 7 & Etsako Central & & & & 6.5 & \\
\hline 8 & Etsako East & 3.15 & 0.4 & 0.37 & 0.7 & -350 \\
\hline 9 & Etsako West & 0.001 & 0.91 & 0.15 & 0.4 & 99.8 \\
\hline 10 & Igueben & 3.77 & 4.09 & 4.05 & 2.5 & -50.8 \\
\hline 11 & Ikpoba - Okha & 1.08 & 0.88 & 1.5 & 0.8 & -35 \\
\hline 12 & Oredo & 4.9 & 4.07 & 4.94 & 1.7 & -188.2 \\
\hline 13 & Orhionmwon & 39.09 & 29.8 & 22.4 & 8.3 & -370.9 \\
\hline 14 & Owan East & 2.22 & 1.63 & 0.8 & 0.3 & -640 \\
\hline 15 & Owan West & 1.89 & 1.25 & 2.08 & 3.8 & -50.3 \\
\hline 16 & Ovia North East & 1.26 & 1.83 & 1.32 & 0.6 & -110 \\
\hline 17 & Ovia South West & 3.53 & 1.61 & 3.69 & 0.5 & -606 \\
\hline 18 & Uhunmwode & 3.19 & 3.62 & 3.38 & 0.9 & -254.4 \\
\hline Average & & 0.92 & 0.44 & 5.9 & 0.8 & -15 \\
\hline Source & 4.652 & 3.523 & 3.663 & 2.067 & -125.1 \\
\hline
\end{tabular}

Source: Computed from the returns of the 18 Local Government Councils to Edo State House of Assembly Committee on investigation of revenue profile of Local Government Councils in Edo State for the period covered.

Table 4 \% Contributed to local government's finances 1993-2006

\begin{tabular}{lllllllll}
\hline Sources & 1993 & 1995 & 1997 & 1999 & 2001 & 2003 & 2005 & 2006 \\
\hline Fed. Rev. All & 93.4 & 88.8 & 89.5 & 91.5 & 95.5 & 93.8 & 95.3 & 96.0 \\
\hline State Rev. All & 0.3 & 0.6 & 0.7 & 0.4 & 0.9 & 0.6 & 0.5 & 0.5 \\
\hline LG. Inter. Rev. & 5.1 & 8.7 & 8.3 & 7.9 & 3.5 & 5.6 & 4.6 & 3.5 \\
\hline Other funds & 1.2 & 2.0 & 1.5 & 0.2 & 0.1 & 0.0 & 0.1 & 0.0 \\
\hline Total & 100.0 & 100.0 & 100.0 & 100.0 & 100 & 100 & 100.0 & 100.0 \\
\hline
\end{tabular}

Source: Imhanlahimi and lkeanyibe (2009:87). 
Table 4 shows a massive state default in disbursement of constitutionally recognized receipt. In addition, internal revenue performance is on speedy decline.

The super story of local decay is not told without capturing the expenditure profile of overdeveloped local bureaucracies. The prospects for improved revenues remain high as table 2 has shown. Not much is however on ground to show for the improved earnings from the federation account. Expenditure pattern is generally tilted towards recurrent and overhead spending with little left for capital project. Tables 5 and 6 which must also be viewed in couplet, capture the super story of bureaucratic over development at the Edo grassroot and the wider national space.

Table 5 captures the relationship between recurrent and capital spending in 18 local councils of Edo-state 2004/2005 and $2005 / 2006$. on the average 60 to $65 \%$ is appropriated for recurrent expenditure.

Table 5 Average Local Government Council Expenditure Profile in Percentage

\begin{tabular}{|c|c|c|c|c|}
\hline $\mathbf{S} / \mathbf{N}$ & Local Govt. Council & Items / Expenditure & Percentage I999-200I & $2004-2006$ \\
\hline \multirow[t]{2}{*}{1} & Akoko Edo & Capital & 30.39 & 32.73 \\
\hline & & Recurrent & 69.61 & 65.27 \\
\hline \multirow[t]{2}{*}{2} & Egor & Capital & 49.2 & 46.20 \\
\hline & & Recurrent & 50.8 & 53.80 \\
\hline \multirow[t]{2}{*}{3} & Esan Central & Capital & 20.85 & 33.3 \\
\hline & & Recurrent & 79.15 & 66.7 \\
\hline \multirow[t]{2}{*}{4} & Esan North East & Capital & 28.7 & $28.85 *$ \\
\hline & & Recurrent & 71.3 & 64.15 \\
\hline \multirow[t]{2}{*}{5} & Esan South East & Capital & 24.6 & 51.57 \\
\hline & & Recurrent & 75.4 & 64.15 \\
\hline \multirow[t]{2}{*}{6} & Esan West & Capital & 29 & $32.8 *$ \\
\hline & & Recurrent & 71 & 66.9 \\
\hline \multirow[t]{2}{*}{7} & Etsako Central & Capital & $52.8 *$ & $40.6 *$ \\
\hline & & Recurrent & 42.7 & 59.0 \\
\hline \multirow[t]{2}{*}{8} & Etsako East & Capital & 52.8 & 33.05 \\
\hline & & Recurrent & 47.2 & 66.94 \\
\hline \multirow[t]{2}{*}{9} & Etsako West & Capital & 34.3 & 39.51 \\
\hline & & Recurrent & 65.7 & 60.49 \\
\hline \multirow[t]{2}{*}{10} & Igueben & Capital & 39.2 & 39.28 \\
\hline & & Recurrent & 60.8 & 60.56 \\
\hline \multirow[t]{2}{*}{11} & Ikpoba-Okha & Capital & 34.9 & 45.83 \\
\hline & & Recurrent & 65.1 & 54.17 \\
\hline \multirow[t]{2}{*}{12} & Oredo & Capital & 15.6 & 36 \\
\hline & & Recurrent & 84.4 & 64 \\
\hline \multirow[t]{2}{*}{13} & Orhionmwon & Capital & 25.1 & 40.03 \\
\hline & & Recurrent & 74.9 & 59.97 \\
\hline \multirow[t]{2}{*}{14} & Owan East & Capital & 49.2 & 51.19 \\
\hline & & Recurrent & 50.8 & 48.81 \\
\hline \multirow[t]{2}{*}{15} & Owan West & Capital & 55.5 & 55.26 \\
\hline & & Recurrent & 44.5 & 44.62 \\
\hline \multirow[t]{2}{*}{16} & Ovia North East & Capital & 38.2 & 41.32 \\
\hline & & Recurrent & 61.8 & 58.68 \\
\hline \multirow[t]{2}{*}{17} & Ovia South West & Capital & 51.02 & $39.66 *$ \\
\hline & & Recurrent & 48.98 & 59.24 \\
\hline \multirow[t]{2}{*}{18} & Uhunwode & Capital & 30.3 & 42.63 \\
\hline & & Recurrent & 69.7 & 57.37 \\
\hline
\end{tabular}

*Difference due to transfer to G.R.B. (General Reserve Balance)

Source: Adapted from the returns of local government councils to Edo State. House of Assembly Committee on Investigation of Revenue Profile of Local Government Councils in Edo State, for the period covered. 
Table 6 LGS' recurrent expenditure in relation to capital expenditure (percent) in Nigeria, 1993-2006.

\begin{tabular}{lll}
\hline Year & Recurrent Exp & Capital Expenditure \\
\hline 1993 & 71.8 & 28.2 \\
\hline 1994 & 77.9 & 22.1 \\
\hline 1995 & 72.8 & 27.1 \\
\hline 1996 & 72.572 .3 & 27.7 \\
\hline 1997 & 72.5 & 27.5 \\
\hline 1998 & 58.6 & 41.4 \\
\hline 2000 & 68.9 & 31.1 \\
\hline 2001 & 61.0 & 39.0 \\
\hline 2002 & 71.6 & 28.4 \\
\hline 2003 & 73.4 & 26.4 \\
\hline 2004 & 58.5 & 41.5 \\
\hline 2005 & 64.1 & 35.9 \\
\hline 2006 & 63.7 & 36.3 \\
\hline $504 r 9$ & 59.8 & 40.2 \\
\hline
\end{tabular}

Sources: Nigerian Government sources (1999, 200I, 2003, 2006) also see Imhanlahimi and lkeayibe (2009:90).

\section{Edo drama: the political economy of rural locale de-poling.}

Ikelegbe (2005:54) summarized the new grassroot optimism when he declared that there is tremendous strengthening of local government funding, structuring, autonomy and democratization. A number of questions however being asked are (I) is this rising federal revenue profile reflected in the performance of councils? (2) are council funds well managed? and (3) are councils constructing local poles of development?.

Can the local councils construct local development poles that can attract development to the grassroots within the existing frame work of limited local retention capacity? What is the character of the development drama that has played out in Edo state in the context of rising revenue profile? In this part of the paper, we want to observe that increased funding and the institutionalization of grassroots, command-type democracy may not limit the constraint of an antidevelopmental fragmentation unleashed by prebendalization (Joseph I99I).

Thus in the context of the peculiar development of the drama that has been played out in the contemporary Edo grass root development profile, a number of observations are instructive. The arrest of 18 possible grass root poles of development following the creation of the existing LGAs is one disappointment of a failed development dream unleashed by a constructivist illusion. Edo state experience has shown consistent rural decay in the face of increased revenue. Only four poles of development; Benin City, Auchi, Ekpoma and Uromi have emerged as new development poles and resource domains.

In deploying the advantage of urban extractive ratio to tap resources from rural LGAs, rising urban poles have reduced the rural LGAs into enclaves of partial resource domains in a reverse transfer relationship that stunts the prospects for the growth of rural local development pole.

In the context of Edo-south senatorial district, reverse resource transfer relationship is actualized in several forms. All senior staff of the four local government councils-Uhumwode, Ohrionmwon, Ovia South-West and Ovia North East reside with their family members in Benin City; Oredo, Egor and lkpoba Okha. They are part of the Benin urban metropolitan economy and development system and not of the rural local government of origin or place of work. The cultural expectation that Benin City is the ultimate home of Edo people tends to predispose them towards Benin property development platform. Local shrines and deities are abandoned while new urban statuses and identities are acquired. This change is enhanced by improved personal and family finances as every one is accepted into Benin as son of the Oba (Obhio - Oba); Similarly, more than 95 percent of the major contractors working for councils also live in Benin City with members of their families.

Inkanyiso, Jnl Hum \& Soc Sci 20I I, 3(I) 
A similar but less centralizing process is also taking root in the other two senatorial districts. While Esan beneficiaries are likely to be pulled towards Ekpoma and Uromi central development poles, North senatorial district beneficiaries are likely to be pulled towards Auchi-North development pole. However, beneficiaries are likely in all cases to build a primary/first home in Benin City and a secondary home in beneficiaries' home-town. In this process, two layers of development poles are under construction in Edo state; central pole around Benin city; and secondary poles around Auchi, Ekpoma and Uromi. These poles are the economic and development poles competing with the partial rural local development poles envisioned in the fragmentation project of local government creation. Urban poles as resource concentration centres also attract labour force (skilled and unskilled); attract critical infrastructure; increase polar tax base and resource profile. The absence of rural poles engenders runaway jobs and opportunities and facilitates rural decay through rural-urban migration. Observation shows that the higher the revenue from the center, the higher the capacity of the urban domain to attract rural beneficiaries to urban polar opportunity.

The logic of the new construction produced a phenomena growth in the number of LGAs from about $30 \mathrm{I}$ in 1984 to its current size of 774 nationwide. This growth is no doubt exponential. It has been driven not by the grassroot, but by a rentier culture provoked by the oilification of the national economy. The development has given rise to prebendalization of state and politics, seeking grassroots corollary in oiling patron/client structure. In this process, the political economy elites of power, seeking integration and co-optation into a complex national system of power emerged to move for fragmentation at the grassroots (Joseph, 1985 \& 1987).

The central objective in the agitation for the creation of more local governments was to create grassroots access to the oil economy and the rentier system for personal transformation. Fragmentation, instead of bringing development to the grass root was a prebendal structure for primitive grassroots accumulation. Thus, while the clamour was for grassroots transformation, the motive was for local elite's access. In a vast majority of cases, it was also a system of patronage and settlement for the local political classes for services rendered during the legitimation challenges faced by the praetorian state. Such prebendal project creates political post not development pole. The post is a patronage system funded with federal allocation. This may explain while states are not sanctioned for default in remittance of state 10 percent statutory allocation to local government councils.

This may also explain why the calls for accountability sound strange at the grassroots. The form and organization of grassroots governance have predicated the collapse of rural infrastructure. It is indeed, an arena of a beastly primitive accumulation driven in contemporary times with an overdeveloped grassroots political bureaucratic machine. Ebohon (2005:209) observed:

Ley's concept of overdeveloped post-colonial state has a bearing on the patterns of development in the Edo state Local government system. Empirical evidence suggests that a vast proportion of centrally and locally derived resources is deployed for bureaucratic ends like salaries and wages, training, touring advances, media patronage and related overhead expenditure.

Tables 5 and 6 illustrate the gross imbalance in the relationship between recurrent and capital spending; this is to the detriment of capital spending. The two immediate implications of this imbalance are (i) the development of rural infrastructure, tend generally to lag, leading to rural-urban migration, rural poverty and rural decay; (ii) the deployment of a vast proportion of grassroots revenue (recurrent) for bureaucratic/political projects, facilitates rural runaway resource towards the centre. The recurrent largesse in the hands of the grassroots political/administrative executives and other senior professional executives who are attracted to the urban development pole, because of their social background characteristics and upward mobility aspirations, often constitute the executive machine for draining the grassroots. In fact, recurrent budgeting has become institutionalized process for constructing grassroots rogue aristocracy with fundamental vested stake in the urban development pole. These rogue aristocrats constitute the rural corollary of the urban central rogue aristocrats and executive political directors of state, who have perfected the art of politics of the belly (Jean-Francois, 1993). In this process, the constructed imbalance between recurrent spending and capital spending has become part of what Aluko (2002) dubbed the institutionalization of corruption in Nigeria

\section{Conclusions and recommendations}

A number of issues that derive from the body of empirical evidence here adduced are observed in this concluding discourse. The first is that the fragmentation of grassroots centres of development into 774, has not produced 774 grassroots development poles. In Edo state, the entire project has played out I 8 local political posts that reverse transfer Federal Statutory allocations to four development poles to the detriment of the rural locale. The de-poling engendered creates more decay than what existed pre-fragmentation. By the character, logic and organization of these political posts; 
they mediate the crisis of rural-urban exploitation and rural-locale de-poling in a self reproduction project typical of patron-client politics. In this context, phenomena growth in statutory and allied revenues accruing to rural-locales has not produced the desired development but undesired decay. Thus, exiting the rural locale rural/LGA for urban sojourn remains the bane of the Edo development profile. Trapped and held hostage by the grassroots rogue aristocrats what alternative options are available?.

\section{Policy target}

I. The initiation of a policy and an administrative programme for the construction and articulation of a mandatory local pole of development in Edo state local government area by January 20 I I;

2. The articulation of a policy programme on the creation of critical infrastructure, which can keep officers and youths on ground within the local government area to stem the incidence of reverse resource flow. This must be in process by January 201 I;

3. The institution of an administrative regime that would concede 70 percent budgetary allocation to capital projects to facilitate the provision of basic amenities. This must happen not later than the first quarter of 20II;

4. A policy of deliberate increase in rural retention ratio and deliberate reduction in urban extractive ratio. This must be operational by January 20II; and

5. Local government councils must be centrally directed to contribute through internal revenue effort at least 25 percent of expendable revenues, starting January $20 \mathrm{II}$ to the funding and running of a Rural Enterprises Development Authority for nurturing rural entrepreneurship in Edo State Local government areas.

\section{Strategies}

I. The creation of necessary infrastructural support schemes in the local government headquarters to stimulate the growth of a new pole of development in each local government area. This must include a housing scheme.

2. A massive and aggressive campaign that aims at attracting private investors to be part of the opportunities that abound in each local government area.

3. Reaching and partnering with indigenes of the LGA in major Nigeria cities and Diaspora on the challenges and potentials of this new strategy and essentialities of a new growth pole;

4. The adoption of a programme of economic restitution for the LGAs by federal and state government, to right the decades of under funding and consequent decay within a new grassroots philosophical and political framework of rural developmentalism. In this context, fiscal federalism that recognizes peculiar environmental development challenges is imperative; and

5. The establishment and construction of a Central Rural Enterprise Development Authority (REDA) to which each local government council must deposit at least 5 percent monthly allocation as seed money for development of rural entrepreneurship in agriculture and small scale industrialization. Access must be based on local indigenship and proven entrepreneurship in proposed project area. This will fast track and sustain the rise of local development poles.

\section{References}

Aghayere, V.O. 1995 “Local Government in Nigeria since 1950” in Ola, R.F. (ed)_Nigeria political system; Inputs, Outputs and Environment, Benin, published by Department of Political Science and Public Administration, University of Benin,) 275-305.

Adamolekun, L. 1983 Public Administration: A Nigerian and comparative perspective. Lagos: Longman.

Aluko, M.A.O. (2002) "The institutionalization of corruption and its impact on political culture and behavior in Nigeria", Nordic Journal of African studies II (3): 393-402.

Bendel state of Nigeria, Local government law 1980 official Gazette_No. I7, vol. I7, Jan.25. 1980.

Central Bank of Nigeria, Annual Reports and Statements of Accounts, Lagos, 1976:77-86.

Central Bank of Nigeria, Economic Reports, First half of 200I - first half of 2005, Lagos, 2006.

Ebohon, S.I. 2005 "Autonomy and local capacity" in tropical focus: The International journal series on Tropical issues._Vol. 6, No. I:196-210.

Ebohon, S.I 1995 "Local government and Rural Resource mobilization" in Ola; R.F.(ED) Nigerian political system, inputs, outputs and environment; (Benin: Department of political science and public Administration, University of Benin,); 306-324.

Erero J. 1998 "Intergovernmental relations of the local level since 1988 Civil service Reforms". The quarterly journal of Administration, vol. XXIX, Nos Iand 2 Oct/Jan, 1997/1998, 264-273.

Gboyega, A. 1987 political values and local government in Nigeria. Lagos: Maltose Press Ltd.

Imhanlahim J. and Ikeanyibe, M.O. 2009 "Local government Autonomy and development of localities in Nigeria: Issues, challenges and suggestions" African journal of stability and development Vol.3 No.2: 76- 102.

Imman B 1990 Local government finance in Nigeria. (Ibadan: Nigerian institute of social and economic research (NISER): 23-50.

Ikelegbe, A 2005 "The Local Government system and grassroots development in Nigeria: Issues, problems and challenges" in A.G. Onokerhoraye and G.E.D. Omuta (eds) perspectives on development: A book in honor of Pius. O. Sada, (Benin-City: centre for population and Environmental development.)

Inkanyiso, Jnl Hum \& Soc Sci 20I I, 3(I) 
Joseph, R.A 1987 Democracy and prebendal politics in Nigeria: The rise and fall of the second Republic. Cambridge: Cambridge University Press.

Joseph, R.A 1985 "The dismal Tunnel from Prebendal Republic to Rogue state in Nigeria", paper presented at the conference on dilemmas of democracy in Nigeria,_University of Wisconsin, November.

Jean-François, B. 1993 The state in Africa: The politics of the belly. London, Longman.

Nigerian Government Sources, "LGS recurrent expenditure in relation to capital expenditure in Nigeria, 1993-2006. (Abuja) 1999, 200I, 2003 and 2006.

Oduola, S.O. 198I "The population factors in allocation of social facilities in Nigeria". In Olowu, (ed) The Administration of social service in Nigeria; the challenge of local governments, Ile-Ife: Local government training programme, unife.

Reports of 18 Local Government Councils to Edo State House of Assembly Committee on investigation of the revenue profile of local government councils in Edo State 1999, 2000, 200 I and 2006 (Benin City): 2002 and 2007.

Wraith, R.(1972) Local Administration in West Africa. London: Allen and Unwin. 